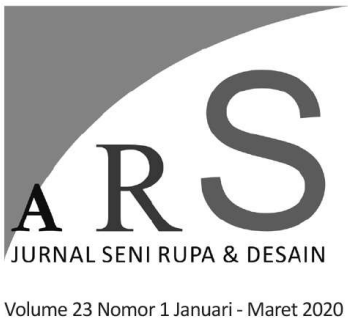

\section{BAMBOO HOUSE, DESAIN INTERIOR BERKELANJUTAN HUNIAN DESA WISATA MINGGIR SLEMAN YOGYAKARTA}

\author{
Yayu Rubiyanti \\ Program Studi Desain Interior, Jurusan Desain \\ FSR ISI Yogyakarta \\ E-mail: ruby.sofyan@gmail.com
}

\begin{abstract}
ABSTRAK
Hunian yang menggunakan material utama bambu merupakan pilihan bagi wilayah yang memiliki sumber daya bambu berlimpah, seperti di desa wisata Bambu Brajan. Seperti juga material rotan, fleksibilitas bahan bambu membuatnya digemari untuk produk kerajinan, furniture, juga beragam bentuk hunian. Hunian bambu yang dibangun dengan menerapkan prinsip desain berkelanjutan dapat dijadikan sebagai solusi untuk mensinergikan berbagai macam potensi yang ada. Keselarasan optimalisasi sumberdaya alam dan manusia untuk menjawab permasalahan hunian adalah tujuan yang ditawarkan penelitian ini. Alternatif desain yang ditawarkan didapat berdasarkan hasil analisa, berupa bentuk hunian dengan penerapan prinsip desain berkelanjutan biomimicry. Pemaparan visual berupa gambar ilustrasi yang diharapkan dapat mempermudah tahap selanjutnya untuk penciptaan prototipe.
\end{abstract}

Kata Kunci: Bamboo House, biomimicry, sustainable design, desa wisata.

\begin{abstract}
House that uses bamboo as main material is an option for areas that have abundant bamboo resources, such as in the Bamboo Brajan tourism village. As well as rattan material, the flexibility of bamboo material makes it popular for handycraft products, furniture, as well as various forms of housing. Bamboo house built by applying sustainable design principles can be used as a solution to synergyze a variety of potentials. The harmony of optimizing natural and human resources to address the problems of occupancy is the objective offered by this research. The alternative designs are obtained based on the results of the analysis, in the form of housing with the application of sustainable biomimicry design principles. The illustration produced is expected to assist the creation of prototype the the next stage.
\end{abstract}

Keywords: Bamboo House, biomimicry, sustainable design, tourism village. 


\section{Pendahuluan}

Bambu adalah rumput raksasa yang tingginya bisa mencapai delapan belas meter saat usia panen empat tahun. Material terbarukan ini banyak disalahpahami sebagai kayu, sehingga car a penanganannya menjadi tidak begitu optimal. Sebagai rumput raksasa bambu sangatlah menarik dan artistik untuk digunakan menjadi bahan utama hunian sebuah Desa Wisata. Desa Wisata Sendangrejo Minggir, Sleman DIY sangat akrab dengan rekayasa dan budidaya bambu, baik sebagai kerajinan, bahan bangunan maupun alat-alat pertanian bahkan alat masak-memasak. Kearifan lokal masyarakat Sendangrejo Minggir, Sleman DIY yang orisinil seharusnya mampu berkontribusi bagi keilmuan desain interior berkelanjutan biomimikri untuk membantu melestarikan alam semesta. Minimnya data dan publikasi ilmiah tentang bagaimana rekayasa desain bambu "sebagai rumput" merupakan peluang sekaligus kontribusi penelitian ini.

Bambu saat dipandang sebagai rumput raksasa akan menjadi sangat berbeda eksekusi artistiknya dibandingkan saat bambu dianggap sebagai kayu. Berapa lama kita salah persepsi terhadap bambu sebagai kayu adalah cikal bakal rendahnya daya jual bambu, masyarakat masih menganggap bambu adalah kayu yang paling murah, gampang disampahkan sekaligus meminggirkan bambu dari dunia desain interior hunian.

Desain interior berkelanjutan biomimikri adalah sebuah prinsip desain yang respek pada sistem alam semesta. Wujud rasa syukur dan sikap bertanggung jawab terhadap kelestarian alam semesta menjadikan desain ini tidak menyisakan ruang pemikiran adanya sampah pada alam semesta. Semua yang ada di alam semesta adalah berkah dan karunia, sehingga perancang harus mempunyai sikap respek pada sistem alam semesta, dengan optimalisasi material bambu sebagai rumput raksasa, dunia desain interior rumah bambu akan mempunyai kesempatan lebih baik.

Kearifan lokal warisan nenek moyang Nusantara dalam menanam bambu, memilih atau memanen bambu sangatlah ilmiah dan merupakan kontribusi keilmuan yang sangat penting dalam dunia desain interior berkelanjutan. Keberhasilan memahami kearifan lokal tersebut kelak akan menumbuhkan gemar menanam dan merawat rumput bambu, karena hanya bambu yang diperlakukan baik akan menghasilkan rumput bambu yang baik pula sebagai material utama desain interior.
Hasil akhir dari kemampuan memahami kearifan lokal tentang cara baru melihat bambu sebagai rumput raksasa diharapkan akan memberi kontribusi keilmuan yang orisinil Jawa bagi dunia hunian rumah bambu sebagai dasar desain interior hunian desa wisata. Tujuan utama penelitian ini adalah membangkitkan kembali nilai tersembunyi dari kredo "Bambu adalah rumput raksasa yang terbarukan".

\section{Metode}

Penelitian ini menggunakan metode peneltian kualitatif, hal ini disebabkan karena kajian tentang efisiensi dan efektivitas penerapan prinsip desain berkelanjutan biomimikri. Metode penelitian pada penelitian ini lebih bertujuan untuk mengetahui tentang efisiensi dan efektivitas penerapan kearifan lokal prinsip desain berkelanjutan biomimikri.

Data penelitian ini bersumber dari artefak, sumber tertulis dan sumber lisan. Pengumpulan data-data dilakukan secara langsung (data primer) maupun tidak langsung terhadap sumber aslinya (data sekunder). Selanjutnya data yang berupa wujud desain itu akan direduksi atau dipilih menggunakan teori penerapan prinsip-prinsip desain berkelanjutan biomimikri yang bersumber pada buku terbitan tahun 2008 yang berjudul Environmentally Responsible Design: Green and Sustainable Design for Interior Designer, pada bagian I: Environtmentally Responsible Interior Design, pada bab I: Global Sustainability: The Macro Perspective, tulisan Louise Jones, Good Design by any other name, Environtmentally responsible design.

Semua data baik yang tertulis maupun lisan, akan diolah dan dianalisis serta disajikan dalam bentuk deskriptif analitik. Populasi penelitian dengan kategori studi kasus ini adalah desa wisata Minggir, Sleman Yogyakarta. Pengambilang sampel dipusatkan terhadap rumah penduduk yang memanfaatkan bamboo sebagai hunian atau bamboo house.

Studi pustaka dilakukan untuk pencarian referensi melalui artikel yang memuat berbagai hal yang berhubungan dengan tanaman bamboo dan rekayasa desain berbahan bamboo serta melalui sumber referensi teoritis (buku) untuk memperoleh informasi mengenai desain interior berkelanjutan biomimikri. Observasi lapangan dan wawancara dilakukan dengan melibatkan beberapa pengrajin dan petani bamboo serta pengelola desa wisata Minggir, desainer dan mahasiswa. 


\section{Hasil Dan Pembahasan}

\section{Analisa Kondisi Wisata Desa Wisata Kerajinan} Bambu Brajan

Desa Wisata Brajan berlokasi di Sendangagung, Minggir, Sleman, Yogyakarta. Desa ini sudah dikenal sebagai salah satu sentra industri kerajinan bambu. Sebagian besar masyarakat desa tersebut berprofesi sebagai pengrajin bambu, beberapa kepala keluarga sudah memiliki showroom. Masyarakat desa wisata Brajan ini sudah banyak menghasilkan berbagai jenis produk yang material utamanya adalah bamboo, lebih spesifiknya adalah produk anyaman bambu.

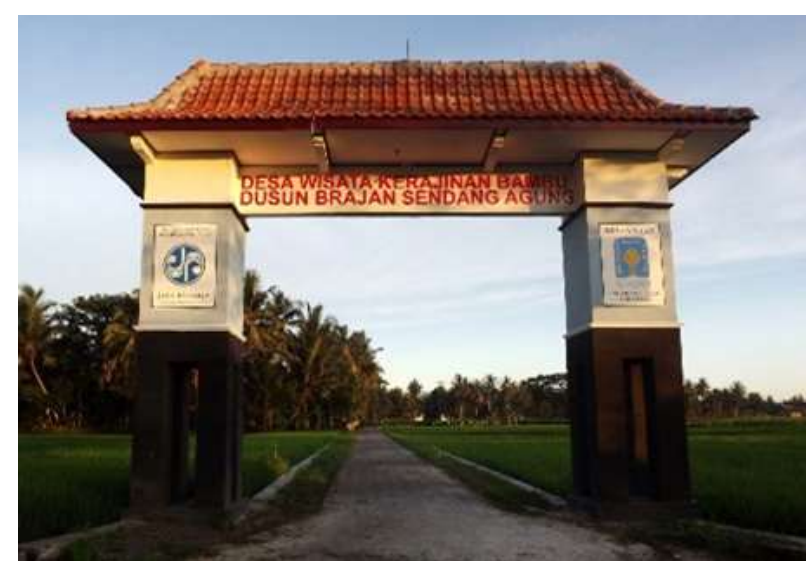

Gambar 1. Pintu Gerbang Desa Wisata Kerajinan Bambu Brajan

(Sumber : Dokumen Peneliti, 2019)

Dalam mengembangkan desa Brajan, dibentuk sejumlah pengurus untuk mengelola desa secara umum dan secara khusus untuk mengembangkan wisata kerajinan sebagai potensi dari sumber daya desa Brajan yang tidak dimiliki oleh desa lainnya. Para pengelola desa terdiri dari penasehat, kepala dusun hingga seksi-seksi yang mengelola bidang kecil secara fokus.
Desa Brajan juga bekerjasama dengan PT. Jasa Raharja dalam mengembangkan potensi wisata kerajinan bambu. Kerjasama tersebut menghasilkan pendanaan pengembangan desa yang digunakan untuk membangun sebuah taman, yang diberi nama Taman Brajan. Taman Brajan merupakan sebuah taman bunga yang dibangun dengan tujuan utama sebagai sarana bermain bagi warga setempat terutama anakanak, namun dalam perkembangannya taman tersebut menjadi salah satu fasilitas wisata bagi pengunjung dan masyarakat umum.

Kerajinan bambu di desa Brajan sudah ada sejak lama, bahkan sebelum menyandang predikat sebagai desa wisata. Desa Wisata Brajan terdapat 75 kepala keluarga, 75\% diantaranya bekerja sebagai pengrajin. Dari jumlah tersebut, terdapat 7 sentra kerajinan bambu yang berperan sebagai sentra utama di desa Brajan, 2 diantaranya telah memiliki showroom di kawasan desa Brajan. Sentra utama berperan sebagai penerima order dari konsumen dan kemudian di didstribusikan kepada sentra lain disekitarnya, umumnya para tetangga. Umumnya produk industri rumahan dikerjakan secara mandiri oleh pemilik sentra. Keterampilan mengolah bambu dilakukan secara turun temurun di desa wisata Brajan.

Cerita singkat mengenai asal muasal desa Brajan berubah menjadi desa wisata kerajinan, yakni dimulai sekitar tahun 1991-2000 terbentuk kelompok usaha di Desa Brajan. Kelompok ini bernama Prinxmas dan memiliki anggota berjumlah 15 (lima belas) orang. Kelompok ini merupakan perintis dari desa Brajan sebagai desa kerajinan bambu, selain itu juga berperan sebagai wadah masyarakat dalam memproduksi, mengembangkan hingga memasarkan produk

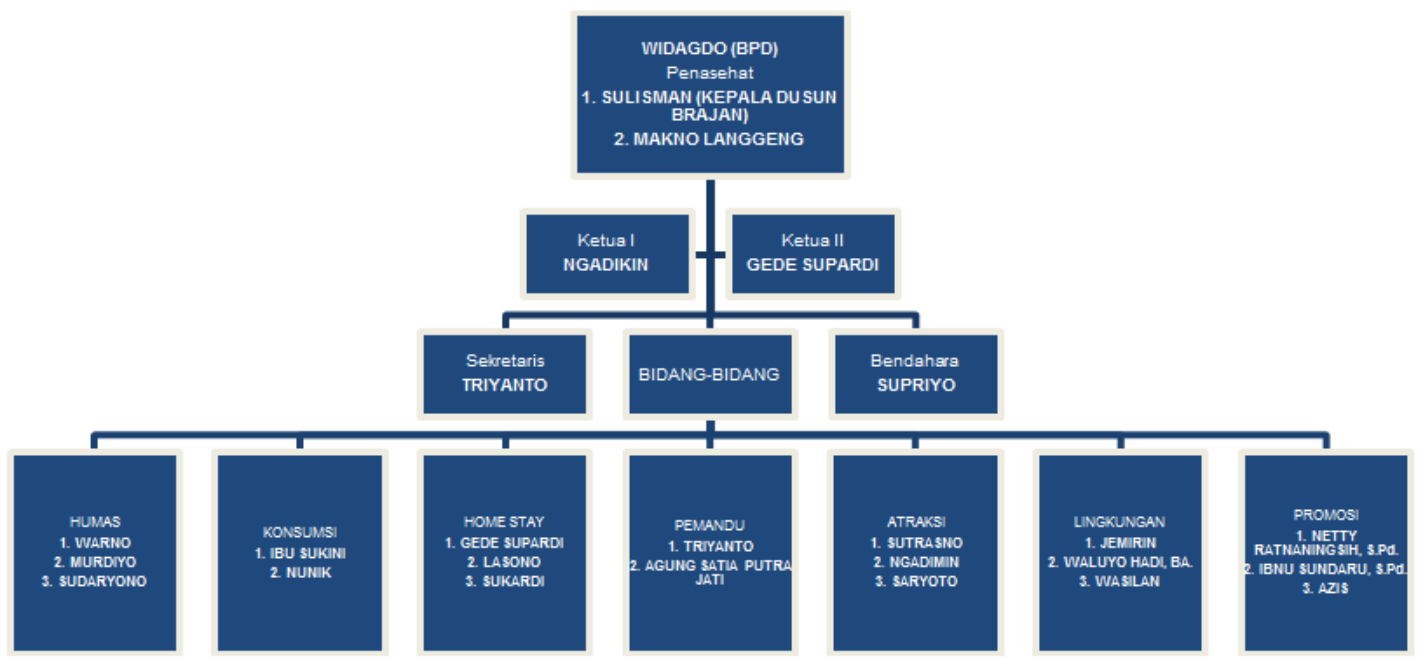

Gambar 2. Struktur Organinsasi Desa Wisata Kerajinan Bambu Brajan (Sumber : Dokumentasi Peneliti, 2019) 
kerajinan ke luar daerah. Namun kelompok ini tidak bisa bertahan lama dan akhirnya bubar, faktor rendahnya daya beli dan minat masyarakat terhadap kerajinan bambu serta tidak adanya regenerasi dari anak muda merupakan alasan kelompok ini tidak bisa bertahan.

Desa Brajan terletak di Sendangagung, daerah Minggir, kabupaten Sleman, Daerah Istimewa Yogyakarta. Sebuah lokasi yang berada di ujung barat dari pusat kota Yogyakarta. Nama desa Brajan diambil dari nama Kyai Brojo Setiko yang merupakan cikal bakal penduduk yang pertama kali menetap disana. Meskipun Desa Brajan merupakan sebuah desa yang kecil, namun memiliki daya tarik melalui produk kerajinan bambu yang dihasilkan dan bahkan telah menembus pasar internasional. (Mehmed Farouqi, 2013, Desa Wisata Brajan, "Sentra Kerajinan Bambu" https://www.kompasiana. com/cyberboypower/5529409a6ea834e41f8b4 5c4/desa-wisata-brajan-sentra-kerajinan-bambu, diakses tanggal 6 Oktober 2019).

Mayoritas masyarakat Desa Brajan awal mulanya memiliki mata pencaharian sebagai petani. Saat kelompok prinxmas mulai menjalankan usaha kerajinan bambu, saat itu tidak banyak masyarakat yang tertarik untuk ikut bergabung. Namun seiring perkembangan teknologi dan maraknya penggunaan media sosial saat ini menjadi salah satu proses penting awal mula meningkatnya permintaan terhadap kerajinan bambu dari desa Brajan. Melalui penggunaan media sosial, kerajinan bambu Brajan semakin banyak dikenal bahkan hingga ke mancanegara.

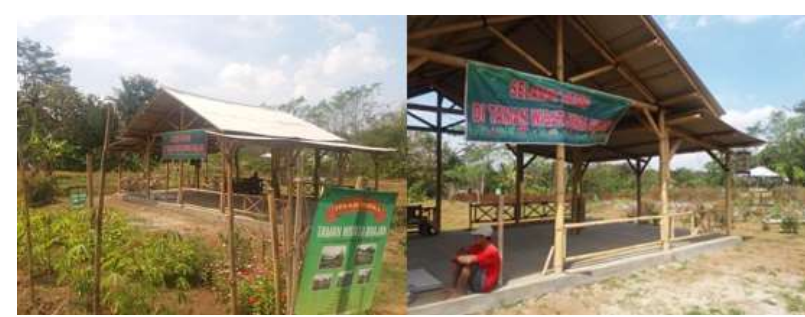

Gambar 3. Proses Pembangunan Pusat Kegiatan Kawasan Taman Brajan

(Sumber : Dokumentasi Peneliti, 2019)

Perusahaan BUMN Telkom menjadi perusahaan yang sangat berkontribusi terhadap titik balik desa Brajan menjadi desa wisata. Telkom dengan koneksi internet broadbandnya menjadi salah satu perusahaan yang secara fokus membantu pengembangan industri kerajinan bambu di Desa Brajan. Salah satu programnya adalah UKM digital melalui bantuan berupa jaringan internet dan hotspot sehingga para UKM Bambu Brajan dapat terdigitalisasi sehingga mampu merambah pasar mancanegara. (Sg, 2017, Desa Wisata Brajan, kerajinan bambu yang mendunia https://www.indotelko.com/liputankhusus/rumah-kreatif-bumn/read/1483413008/ desa-wisata-brajan-kerajinan-bambu-yangmendunia, diakses tanggal 6 Oktober 2019).

Kehadiran wisatawan lokal maupun asing yang datang karena tertarik dengan produk kerajinan bambu Brajan tidak sedikit, bahkan pihak pengelola desa mengaku sedikit kewalahan dengan jumlah permintaan produk yang masuk sehingga secara swadaya memberikan pelatihan menganyam bambu kepada warga agar dapat mampu memnuhi permintaan konsumen. Para pengrajin hasil didikan kemudian akan memproduksi barang kerajinan yang akan dipasarkan di salah satu galeri yang ada untuk bisa dinikmati maupun dibeli sebagai buah tangan oleh wisatawan yang berkunjung ke Desa Wisata Brajan.

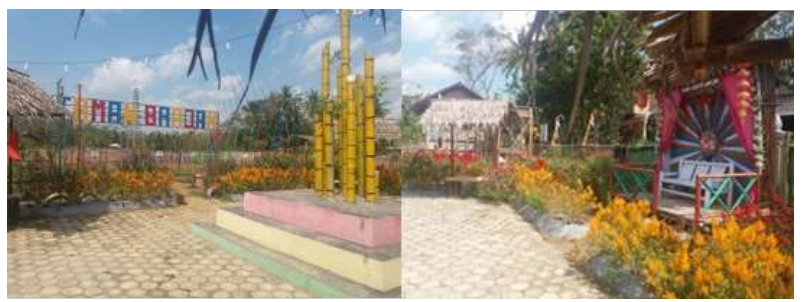

Gambar 4. Pintu Masuk (kiri) dan suasana kawasan Taman Brajan

(Sumber : Dokumentasi Peneliti, 2019)

Proses terjadinya perubahan Desa Brajan dari semula sebagai desa biasa menjadi desa wisata dimulai sekitar tahun 2006. Melalui Dinas Perindustrian Kabupaten Sleman, Desa Brajan mulai dicanangkan sebagai Desa Wisata dengan konsep Desa Wisata Cinderamata berupa kerajinan anyaman bambu. Meski sempat vakum dalam beberapa tahun, namun masyarakat mulai kembali mengelola dan melakukan pengembangan kembali hingga sekarang. Dengan bantuan mitra binaan dari UII dan PT. Jasa Raharja Desa Brajan mulai berkembang. Dengan kondisi tersebut masyarakat Desa Brajan mulai menekuni kerajinan anyaman bambu hingga 
menjadikan pekerjaan tersebut menjadi pekerjaan tetap (pokok) mereka. Bahkan beberapa dari mereka sudah mampu mendirikan showroom di rumah mereka.

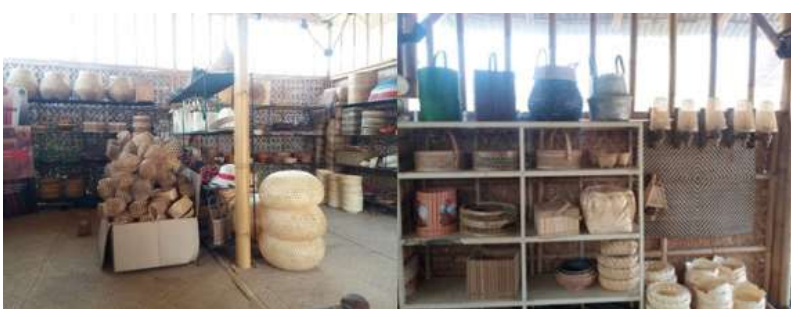

Gambar 5. Showroom milik warga beserta beberapa hasil produk kerajinannya.

(Sumber : Dokumentasi Peneliti, 2019)

Peresmian desa wisata Brajan diikuti dengan pendirian gapura masuk desa yang merupakan bantuan resmi dari Universitas Islam Indonesia dan PT. Jasa Raharja. Gapura tersebut diresmikan oleh Bupati Sleman dan disaksikan oleh Dinas terkait.

\section{Analisis Problem dan Potensi Bambu di Sentra Industri Kerajinan Desa Wisata Bambu Brajan}

Berdasarkan hasil pengalaman mengamati sentra industri bambu di Desa Wisata Brajan, sebanyak 75\% penduduk Desa Wisata Brajan berprofesi sebagai pengrajin bambu, namun hanya terdapat 7 sentra kerajinan bambu yang berperan sebagai sentra utama, dan 2 diantaranya telah mendirikan showroom yang letaknya disekitar Taman Brajan. Warga desa hanya membuat produk sederhana, beberapa kerajinan pasar dan hanya dipasarkan di pasar tradisional. Pada awalnya, warga desa Brajan hanya membuat produk sederhana. Namun sejak adanya kerjasama antara pengelola desa dengan PT. Jasa Raharja dan perusahaan exportir, warga desa Brajan mulai mampu memasarkan produknya keluar kota, hingga keluar negeri. Peneliti melihat adanya kemajuan desain dari produk kerajinan yang dihasilkan, terlihat semakin bervariasi.

Peneliti melihat bahwa dari hasil inovasi tersebut masyarakat Brajan mampu menghasilkan berbagai produk fungsional hingga produk home décor. Produk yang dihasilkan oleh masyarakat Desa Wisata Brajan dibagi menjadi 2 fokus pemasaran. Untuk pasar ekspor, masyarakat Desa Wisata Brajan melakukan treatment (perawatan) khusus pada tahapan finishing. Hal ini dilakukan karena pada saat proses pengiriman ke negara tujuan membutuhkan waktu yang tidak singkat, oleh karena itu perlu finishing yang mampu menjaga kualitas produk mereka. Kualitas produk yang dihasilkan juga akan melalui tahap quality control oleh eksportir untuk mengetes kualitas produk. Pada tahapan ini masyarakat Desa Wisata Brajan hanya berperan sebagai produsen, sementara proses packaging hingga pengiriman dilakukan oleh eksportir yang telah melakukan kerjasama sebelumnya.

Tabel 1. Contoh hasil inovasi produk export di Desa Wisata Kerajinan Bambu Brajan

\begin{tabular}{|c|c|c|c|}
\hline $\mathrm{NO}$ & GAMBAR & KETERANGAN & PRODUKSI \\
\hline 1 & & $\begin{array}{l}\text { Hasil olahan } \\
\text { berupa hiasan } \\
\text { dinding dengan } \\
\text { motif (ornamen) }\end{array}$ & \multirow{5}{*}{$\begin{array}{l}\text { Hasil produksi } \\
\text { untuk ekspor } \\
\text { ke luar negeri } \\
\text { (Dubai), } \\
\text { permintaan } \\
\text { pasar luar } \\
\text { negeri lebih } \\
\text { mengedepankan } \\
\text { hasil akhir } \\
\text { (finishing). } \\
\text { Untuk model \& } \\
\text { motif mereka } \\
\text { lebih menyukai } \\
\text { motif anyaman } \\
\text { truntum } \\
\text { dengan } \\
\text { kombinasi } \\
\text { warna-warna } \\
\text { cerah }\end{array}$} \\
\hline 2 & & $\begin{array}{l}\text { Hasil olahan } \\
\text { berupa box } \\
\text { multifungsi } \\
\text { dengan motif } \\
\text { anyaman } \\
\text { truntum }\end{array}$ & \\
\hline 3 & & $\begin{array}{l}\text { Hasil olahan } \\
\text { berupa kap } \\
\text { lampu dengan } \\
\text { motif anyaman } \\
\text { truntum }\end{array}$ & \\
\hline 4 & & $\begin{array}{l}\text { Hasil olahan } \\
\text { berupa wadah } \\
\text { buah dengan } \\
\text { anyaman warna } \\
\text { kombinasi }\end{array}$ & \\
\hline 5 & & $\begin{array}{l}\text { Hasil olahan } \\
\text { berupa box } \\
\text { multifungsi } \\
\text { dengan motif } \\
\text { anyaman } \\
\text { truntum }\end{array}$ & \\
\hline
\end{tabular}

Inovasi Produk Kerajinan Bambu Untuk Pasar Ekspor (Sumber : Dokumen Peneliti, 2019)

Pada pasar lokal masyarakat Desa Wisata Brajan memasarkan produk mereka di berbagai pasar sentra kerajinan. Jangkauan pemasaran mereka di beberapa kota besar di Indonesia seperti Bandung, Banten, Yogyakarta, hingga Bali. 
Tabel 2. Hasil inovasi produk untuk pasar lokal di Desa Wisata Kerajinan Bambu Brajan

\begin{tabular}{|c|c|c|c|}
\hline $\mathrm{NO}$ & GAMBAR & KETERANGAN & PRODUKSI \\
\hline 1 & & $\begin{array}{l}\text { Hasil olahan } \\
\text { berupa box } \\
\text { multifungsi } \\
\text { dengan motif } \\
\text { anyaman silang }\end{array}$ & \multirow{5}{*}{$\begin{array}{l}\text { Hasil produksi } \\
\text { untuk pasar } \\
\text { lokal, biasanya } \\
\text { berupa produk } \\
\text { fungsional } \\
\text { dengan motif } \\
\text { anyaman yang } \\
\text { sederhana dan } \\
\text { kombinasi } \\
\text { warna yang } \\
\text { monokrom } \\
\text { (tidak banyak } \\
\text { warna) }\end{array}$} \\
\hline 2 & & $\begin{array}{l}\text { Hasil olahan } \\
\text { berbentuk } \\
\text { seperti mangkuk } \\
\text { dengan motif } \\
\text { anyaman } \\
\text { silang yang } \\
\text { dikombinasi }\end{array}$ & \\
\hline 3 & & $\begin{array}{l}\text { Hasil olahan } \\
\text { berbentuk } \\
\text { pincuk }\end{array}$ & \\
\hline 4 & & $\begin{array}{l}\text { Hasil olahan } \\
\text { berupa wadah } \\
\text { aksesoris dengan } \\
\text { motif anyaman } \\
\text { berlubang }\end{array}$ & \\
\hline 5 & & $\begin{array}{l}\text { Hasil olahan } \\
\text { berupa wadah } \\
\text { aksesoris dengan } \\
\text { motif anyaman } \\
\text { berlubang } \\
\text { dengan } \\
\text { kombinasi motif } \\
\text { silang }\end{array}$ & \\
\hline
\end{tabular}

Inovasi Produk Kerajinan Bambu Untuk Pasar Ekspor (Sumber : Dokumen Peneliti, 2019)

Melihat problem utama dari sentra kerajinan bambu di Desa Wisata Bambu Brajan, hal yang paling krusial adalah ketersediaan bambu sebagai bahan baku kerajinan produk bambu. Sebagai langkah untuk memenuhi kebutuhan bahan baku berupa bambu, masyarakat Desa Brajan mendatangkan pasokan bambu dari daerah Nanggulan dan Sentolo Kulonporgo. Para pengrajin mendapatkan bahan baku tersebut langsung dari petani bambu sehingga mereka memperoleh harga yang lebih murah.

Seperti dikutip dari penelitian Setya Budi Astanto (2016) bahwa bambu adalah rumput raksasa yang merupakan material terbarukan karena bisa dipanen setiap empat tahun dengan panjang maksimal 18 meter. Berdasarkan ukuran batang, bambu dapat dikelompokkan menjadi 3 golongan yaitu bambu kecil, sedang, dan besar. Contoh jenis bambu dari kelompok tersebut adalah Bambu Apus (kecil), Bambu Legi (sedang), dan Bambu Petung (besar).
Jenis bambu yang digunakan untuk produk kerajinan di Desa Wisata Brajan adalah bambu apus, karena memiliki sifat yang kuat lentur dan bentuknya yang cenderung lebih lurus. Bambu Apus (Gigantochloa Apus) adalah jenis bamboo yang tersedia melimpah dan akrab dengan keahlian masyarakat Indonesia karena ringan dan berukuran lebih kecil. Sedangkan bambu yang paling kuat adalah bambu Petung (Dendrocalamus Asper), biasanya digunakan untuk konstruksi bangunan karena tersedia melimpah di seluruh Indonesia.

Melihat fenomena yang ada, masyarakat yang tinggal di sentra industri bambu Desa Wisata Brajan yang lekat dengan keahlian tukang (craftsmanship) yang turun temurun tidak diimbangi dengan pengelolaan bambu sebagai bahan baku utama sekaligus identitas dari Desa Wisata Brajan. Kurangnya pemahaman masyarakat Desa Brajan tentang cara penanganan bambu, mulai dari pembibitan atau tata cara pembudidayaan hingga cara panen bambu yang baik menjadikan tanaman bambu di daerah Brajan tidak bertahan lama.

Desa Brajan kewalahan dengan pesanan konsumen yang melimpah terhadap produk kerajinan bambu, pada saat itu warga tidak mampu mengendalikan pengambilan bahan baku dari alam, panen bambu dilakukan secara berlebihan dan tidak diimbangi dengan pembudidayaan yang benar. Sehingga dalam waktu yang singkat, Brajan yang awalnya memiliki kebun bambu yang cukup rindang hingga kini berakhir harus mendatangkan bambu dari kota lain. Lahan yang semula menjadi tempat tumbuhnya bambu mulai berubah menjadi rumah warga, sehingga kondisi ini menyebabkan semakin berkurangnya lahan untuk menumbuhkan kembali tanaman bambu di Desa Brajan.

Pemahaman bambu sebagai material terbaharukan perlu disosialisasikan kembali kepada sebagian besar masyarakat, sehingga potensi material bisa dimaksimalkan Namun meskipun demikian, eksploitasi besar-besaran tanpa adanya strategi berkelanjutan dari sebuah konsumsi bahan baku juga tidak akan berjalan maksimal bahkan hasilnya akan cenderung nihil. Kearifan lokal sejalan dengan konsep berkelanjutan yang akhir-akhir ini mulai kembali dimunculkan, padahal ini sudah dilakukan oleh nenek moyang sejak lama.

Masyarakat Jawa percaya dengan pranata mangsa, sehingga zaman dahulu nenek moyang 
kita ketika akan melakukan hal yang menyangkut dengan pertanian pasti selalu memeriksa kalender. Begitu juga dengan waktu terbaik dalam memanen bambu (secara penebangan tradisional) tidak bisa sembarang waktu, namun harus dilakukan pada musim tertentu. Pranata mangsa memiliki 12 musim (mangsa). Musim terbaik untuk melakukan pemanenan adalah pada mangsa tuwa, yaitu mangsa kasanga (ke-9), kasadasa (ke-10), dan dhesta.

Musim kasanga terjadi pada tanggal 1 - 25 Maret dengan ciri-ciri : padi berbunga, jangkrik mulai muncul, tonggeret dan gangsir mulai bersuara. Musim kasadasa (ke-10) sekitar akhir bulan Maret hingga pertengahan April, dan memiliki ciri-ciri padi mulai menguning, telur burung kecil mulai menetas. Mangsa Dhesta (ke11) sekitar pertengahan April hingga pertengahan Mei dengan ciri musim : burung memberi makan anaknya, buah randu mekar, dan sebagainya. (Tommy Apriando, 2015, Brubuh, Kearifan Masyarakat Jawa Menjaga Hutan, https://www. mongabay.co.id/2015/02/12/brubuh-kearifanmasyarakat-jawa-menjaga-hutan/, diakses pada tanggal 7 Oktober 2019).
Penebangan bambu dilakukan pada mangsa kasanga, hal tersebut dilakukan karena bamboo yang dihasilkan memiliki kandungan glukosa paling rendah sehingga tidak mudah dimakan serangga dan memiliki tingkat kelenturan paling tinggi. Dalam proses pemanenan bambu, dapat terlihat bahwa bambu yang tua dan siap untuk dipanen biasanya berada ditengah rumpun dan dikelilingi oleh anak-anak bamboo (tunas). Sehingga diharapkan ketika bamboo tersebut akan dipanen maka tunas yang ada kemudian dipindahkan ke lahan yang baru untuk ditanam.

\section{Analisis Problem Hunian Desa Wisata Kerajinan Bambu Brajan}

Bentuk hunian di Desa Wisata Kerajinan Bambu Brajan beragam, mulai dari bangunan batu bata berbentuk sederhana, hingga tipe bangunan baru. Tidak terdapat ciri khas tertentu seperti menerapkan referensi arsitektural tertentu yang membedakan bangunan hunian di Desa Wisata Brajan dengan desa lainnya. Beberapa warga memberikan area tambahan di bangunan rumah tinggal mereka untuk mengakomodasi kebutuhan akan kegiatan produksi kerajinan bambu mereka.
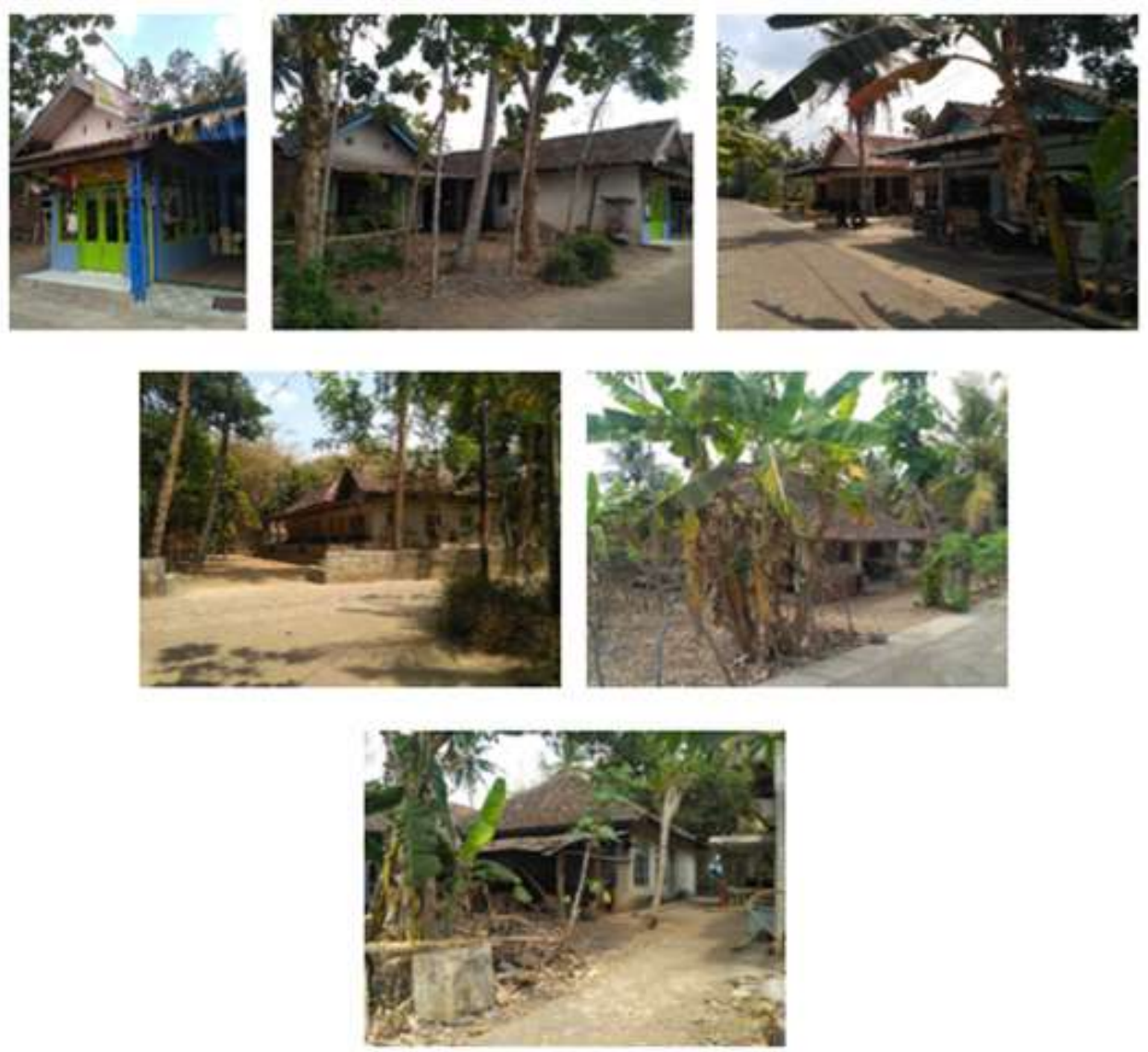

Gambar 6. Foto Beberapa Rumah Warga Desa Brajan (Sumber : Dokumentasi Peneliti, 2019) 
Peneliti mengamati dua hunian sekaligus showroom milik warga desa.

(1) Hunian Bapak Triyanto, pemilik showroom Setia Karya Craft. Selain sebagai tempat tinggal, kegiatan produksi kerajinan bambu dilakukan pada area teras (bagian depan rumah tinggal) dan dengan melakukan penambahan bangunan baru yang berada disebelah hunian. Area teras rumah difokuskan untuk proses kegiatan penganyaman, finishing, serta sebagai area pajang. Sedangkan area bangunan baru,
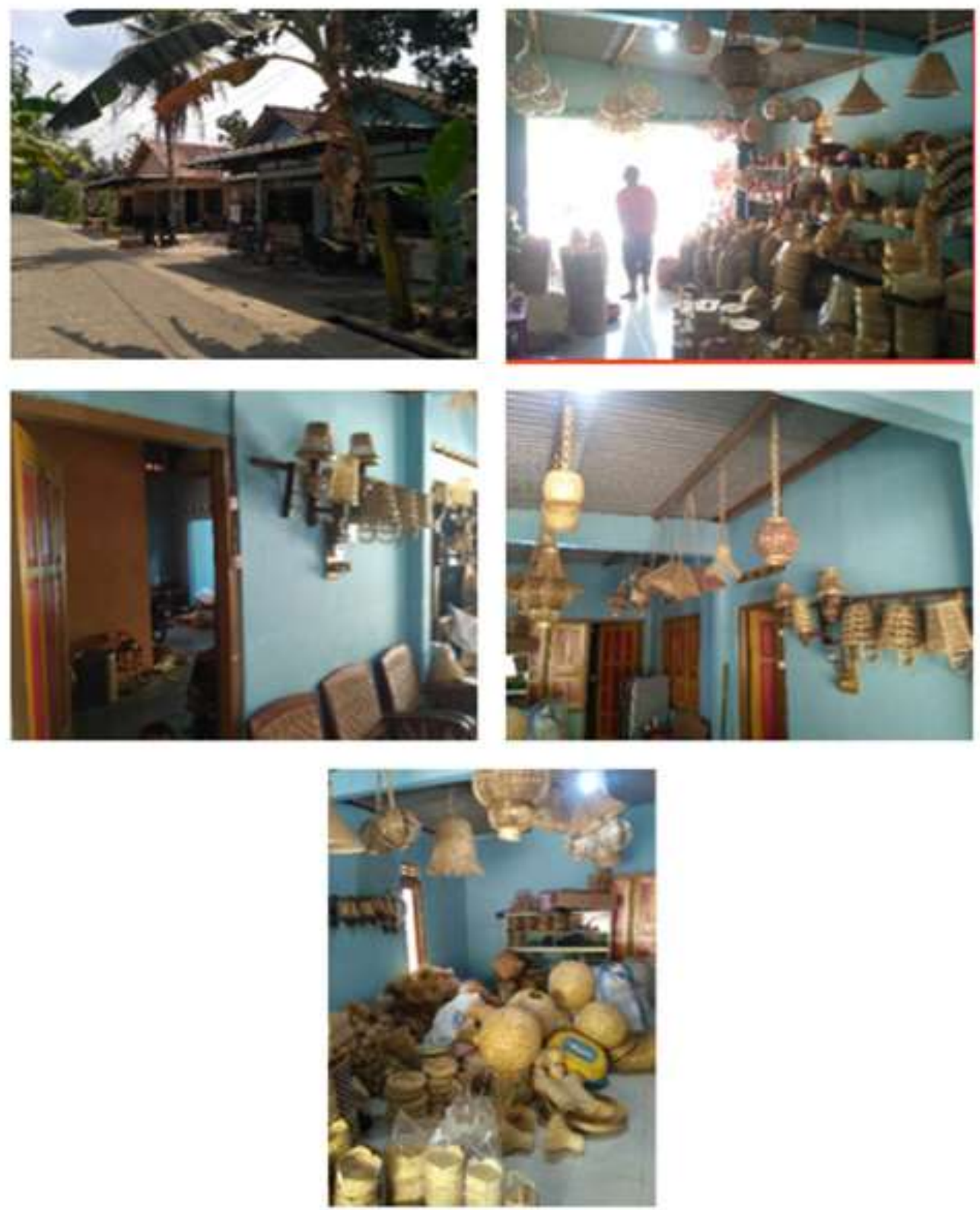

Gambar 7. Foto showroom pribadi milik bapak Wahyu.

(Sumber : Dokumentasi Peneliti, 2019) 
Peneliti mengamati bahwa hunian di Desa Brajan cenderung dihuni oleh keluarga dengan jumlah anggota yang cukup banyak dikarenakan hunian-hunian tersebut diwariskan secara turun temurun sehingga memungkinkan adanya lebih dari satu generasi dalam satu hunian.

Dengan adanya area produksi yang menjadi satu dengan hunian menyebabkan bangunan hunian memiliki fungsi tambahan untuk mendukung kegiatan produksi kerajinan tersebut, seperti fungsi untuk produksi, fungsi sebagai ruang penyimpanan bahan dan material produksi. Setia Karya Craft merupakan contoh hunian yang sekaligus membuka showroom untuk memajang karya-karya kerajinan yang diproduksinya. Diluar itu, bangunan hunian yang mencakup area produksi dan showroom juga perlu mendukung kegiatan-kegiatan desa wisata pada umumnya seperti workshop, pelatihan, dan kunjungan wisata, dan sebagai homestay.

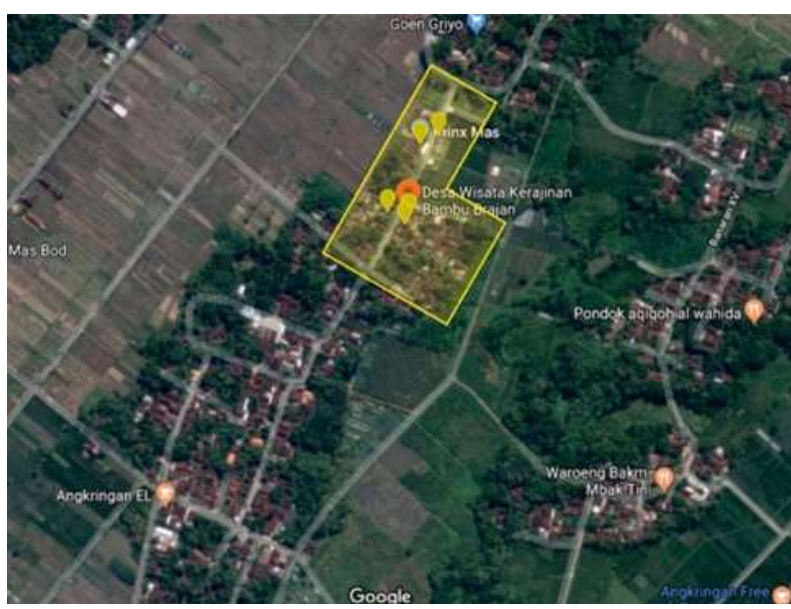

Gambar 8. Area Aktif Kegiatan Wisata dan Produksi Kerajinan Bambu di Desa Wisata Brajan (Sumber : Google Map, 2019)

Keterangan :

Area aktif produksi

Showroom

Kegiatan wisata dan produksi kerajinan bambu berpusat pada satu area, yaitu area di sekitar Taman Wisata Desa Brajan. Terdapat dapat 4 showroom pribadi (Prink Mas, Supriyo, Suyatno, Setia Karya Craft) milik warga dan 1 showroom milik desa (Pring Gedhe). Semua showroom pribadi letaknya menjadi satu dengan area hunian pemilik, sedangkan untuk showroom dibangun tidak menyatu dengan rumah warga, letaknya berada di sebelah taman wisata.

Setiap produksi di dalam satu showroom dikerjakan oleh penghuni (anggota keluarga) rumah dimana showroom itu berada atau mempekerjakan warga atau tetangga lain sesama pengrajin dan juga dapat bekerja sama dengan UKM lain. Beberapa warga menjalankan kegiatan produksinya sendiri yang lebih kecil dibanding dengan produksi showroom.

Pola perubahan perilaku yang dihasilkan dari hunian masyarakat Desa Brajan yang awalnya berupa hunian tinggal biasa dan kemudian mendapat fungsi tambahan sebagai tempat produksi serta showroom kerajinan kemudian mengkondisikan mereka menjadi sangat terbiasa dengan kondisi tersebut meskipun sangat tidak ideal.

\section{Penerapan konsep biomimikri pada hunian Desa Wisata Kerajinan Bambu Brajan.}

Dalam buku berjudul "Environmentally Responsible Design: Green and Sustainable Design for Interior Designer" karya Louise Jones telah dijelaskan bahwa prinsip desain berkelanjutan memiliki tujuan untuk menciptakan lingkungan binaan yang mendukung keseimbangan serta kelestarian lingkungan. Melalui prinsip tersebut, diharapkan masyarakat terutama para perancang mampu menciptakan desain lingkungan yang mampu menjaga keseimbangan ekosistem masa sekarang maupun masa yang akan datang. Prinsip biomimicry merupakan prinsip pertama diantara enam prinsip desain berkelanjutan.

Prinsip biomimicry mengajarkan manusia untuk menghormati alam semesta, dijelaskan pula dalam prinsip ini bahwa manusia dituntut untuk menghormati alam. Sesuai dengan kata biomimicry yang artinya meniru atau mengikuti alam, seperti yang dikatakan oleh Janine Benyus, prinsip ini juga memberikan panduan dalam merancang sebuah karya desain sesuai dengan kaidah desain berkelanjutan.

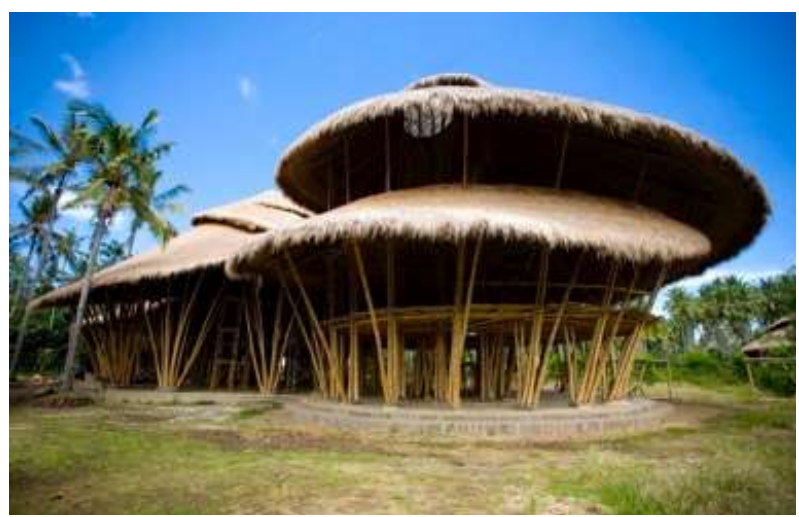

Gambar 9. The Green School menerapkan prinsip biomimicry

(Sumber : https://www.archdaily.com/81585/the-greenschool-pt-bambu/5012b12f28ba0d147d00048a-thegreen-school-pt-bambu-photo. 10/9/2019 12.09 PM) 
Pemanfaatan kekayaan alam sesuai dengan karakteristik beserta sistemnya merupakan pijakan utama dalam prinsip desain berkelanjutan. Memanfaatkan sebuah material sesuai dengan karakteristik alaminya merupakan cara pengungkapan secara jujur terhadap sebuah material.

Sesuai dengan sifat alami bambu yang lentur, salah satu pemanfaatan yang dapat dilakukan adalah dengan metode anyaman. Anyaman merupakan salah satu bentuk hasil karya tangan dengan teknik menindih, menyilang, dan menekuk. Sebelum menjadi bahan anyaman, bambu harus diproses terlebih dahulu. Bambu Apus adalah jenis bambu yang paling sering diolah menjadi bahan anyaman karena sifatnya yang kuat serta lentur sehingga mudah dibentuk.

Proses pengolahan bambu yang umum dilakukan oleh masyarakat Indonesia dimulai dari penebangan bambu hingga tahap finishing. Dengan mengacu pada pengendalian waktu tebang yang merupakan bagian dari local wisdom, hal tersebut juga sekaligus dapat memberi manfaat terhadap daya tahan bambu. Tahapan paling penting dari pengolahan bambu adalah proses pengawetan, umumnya dilakukan dengan perendaman dengan air. Metode ini umum dilakukan karena terbilang sederhana dan minim biaya. Selain itu metode ini dianggap memenuhi prinsip menghargai alam semesta karena tidak menggunakan bahan kimia yang merusak alam melainkan memanfaatkan air sebagai media pengawet bambu yang alami.

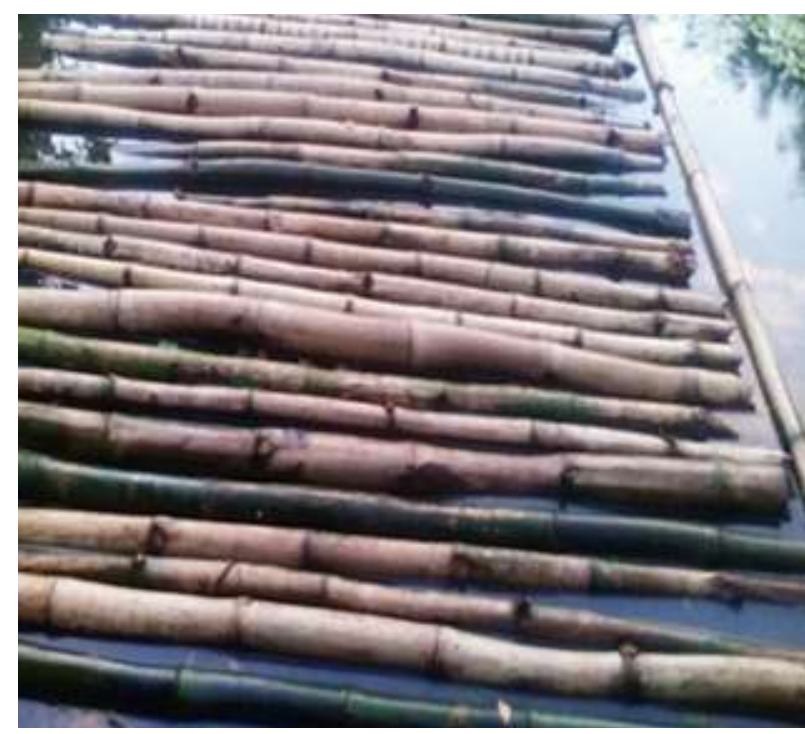

Gambar 10. Proses perendaman bambu dengan menggunakan air sebagai pengawet alami.

(Sumber: Akinlabi, Anane-Fenin, \& Akwada, 2017)
Tujuan akhir dari proses perendaman adalah menekan serangan kumbang bubuk, namun waktu perendaman dianjurkan sebaiknya tidak lebih dari satu bulan. Metode ini cocok diterapkan pada bamboo yang akan digunakan sebagai konstruksi bangunan. Setelah selesai dengan proses pengawetan, kemudian bamboo akan dipisahkan dari kulit luarnya untuk mendapatkan bilah-bilah bambu, kemudian dijemur untuk dikeringkan sehingga dapat dianyam.

Hasil pengamatan terhadap hunian bambu dari berbagai negara, bambu banyak digunakan sebagai material utama dengan tanpa menghilangkan sifat utamanya yakni lentur, kuat serta berkesan ringan. Peneliti mengamati bahwa bambu sebetulnya sangat potensial untuk dibuat sebagai hunian yang nyaman serta estetis serta relevan dengan prinsip desain berkelanjutan. Hunian berbahan bambu juga memberikan banyak pelajaran kepada manusia, terutama dua hal yakni teknik pertukangan yang dapat terus dilestarikan serta isu kelestarian bambu.
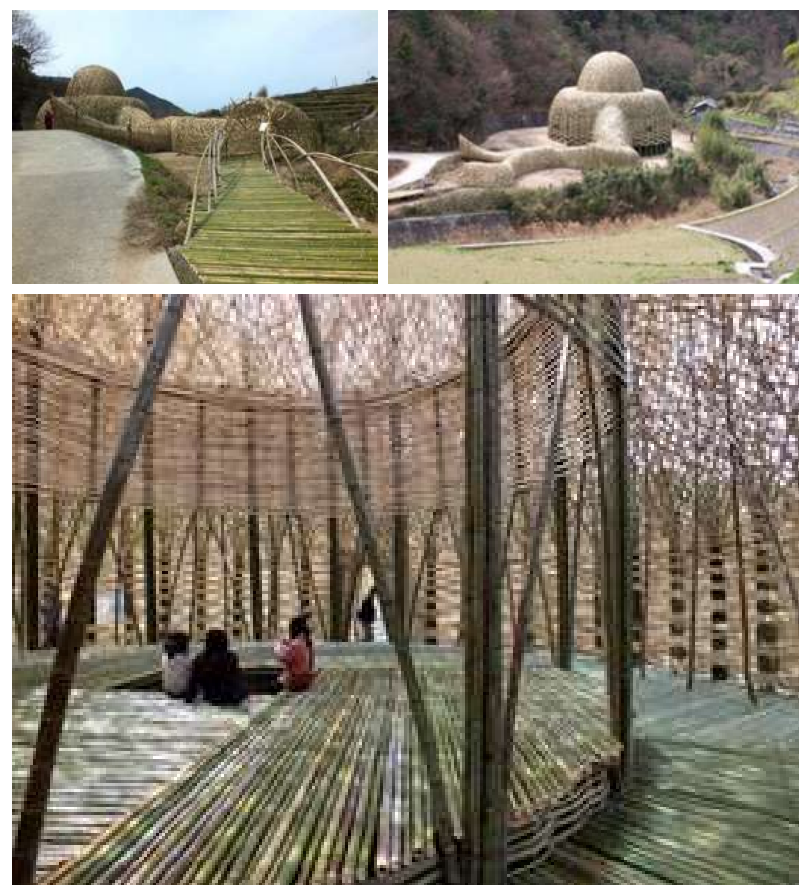

Gambar 11. Penerapan biomimicry serta anyaman bambu pada hunian.

(Sumber : https://www.setouchiexplorer.com/lightshodoshima/ 10/9/2019 13.22 PM)

Dengan melihat daftar kebutuhan yang utama dari Desa Brajan sebagai Desa Wisata, banyak fasilitas penunjang yang masih belum dihadirkan. Sejalan dengan yang pernah dikemukakan oleh Windu pada Laporan 
Konferensi Internasional mengenai Pariwisata Budaya (1993), peneliti sepakat bahwa daya tarik sebuah Desa Wisata Kerajinan Bambu Brajan bisa dilakukan dengan melaksanakan pembangunan fasilitas dan kegiatan.

Peneliti melihat kesenjangan antara apa yang terlihat dilapangan dengan apa yang secara ideal harus dihadirkan di Desa Wisata Bambu Brajan. Pendekatan pembangunan yang dilakukan adalah melalui peningkatan kualitas homestay dan guesthouse yang ada di Desa Wisata Brajan melalui pendekatan eco-lodge. Hal tersebut bisa dilakukan dengan cara melakukan pengembangan desain yang menerapkan prinsip biomimicry terhadap homestay yang ada maupun melakukan pembangunan baru di Desa Wisata Brajan.

Selain ecolodge yang menyangkut homestay dan guesthouse, bangunan lainnya yang bisa dibangun adalah hunian yang diperuntukan bagi komunal sebuah Desa Wisata seperti balai pertemuan desa, untuk mengakomodir pertemuan dengan wisatawan, toilet umum, dan galeri (showroom) yang dapat memamerkan hasil produksi dari Desa Wisata Kerajinan Bambu Brajan.

\section{Hasil Rekayasa Biomimicry terhadap hunian bambu}
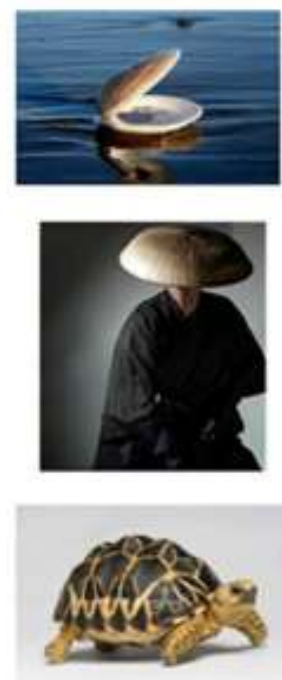
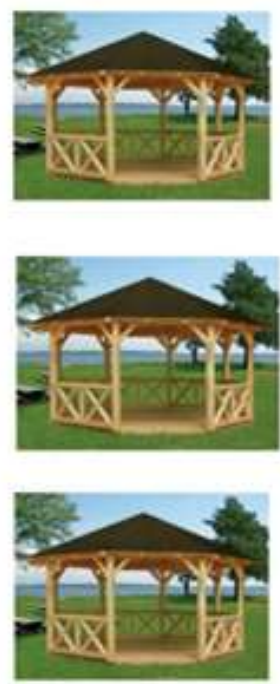
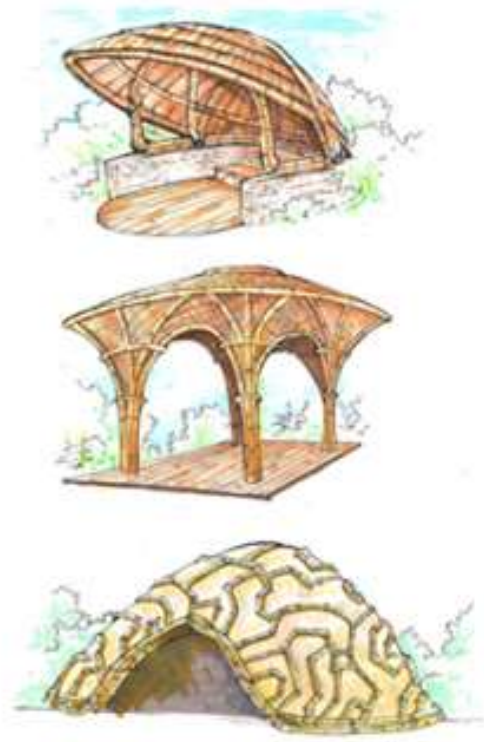

Gambar 12. Hasil rekayasa penerapan biomimicry pada hunian bambu untuk Desa Wisata Kerajinan Bambu Brajan (a).

(Sumber : Analisis peneliti, 2019)
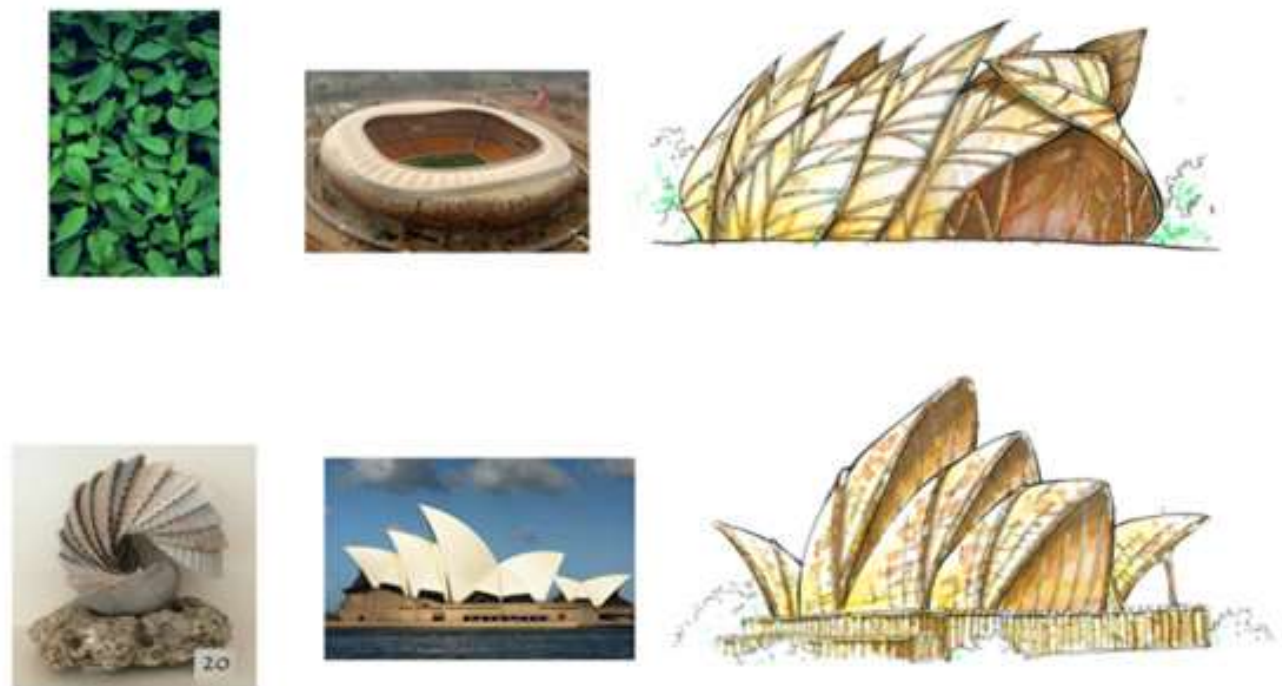

Gambar 13. Hasil rekayasa penerapan biomimicry pada hunian bambu untuk Desa Wisata Kerajinan Bambu Brajan (b). (Sumber : Analisis peneliti, 2019) 

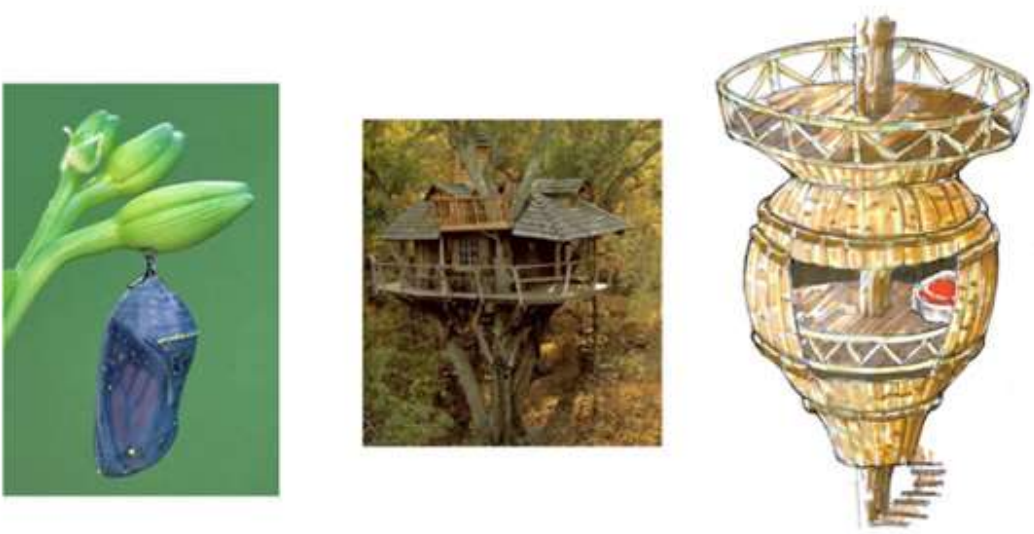

Gambar 14. Hasil rekayasa penerapan biomimicry pada hunian bambu untuk Desa Wisata Kerajinan Bambu Brajan (c).

(Sumber : Analisis peneliti, 2019)
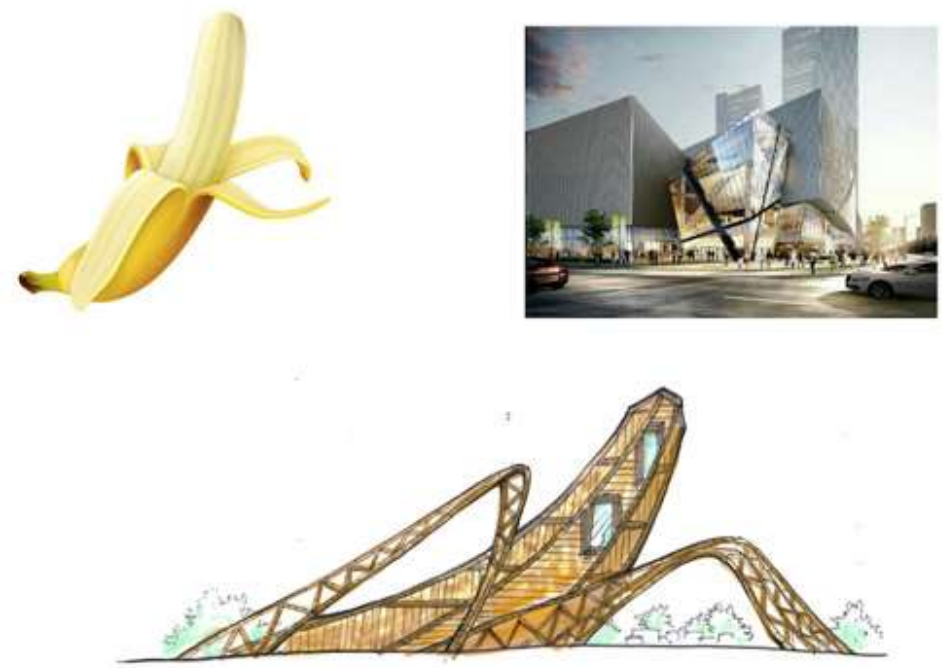

Gambar 15. Hasil rekayasa penerapan biomimicry pada hunian bambu untuk Desa Wisata Kerajinan Bambu Brajan (d).

(Sumber : Analisis peneliti, 2019)
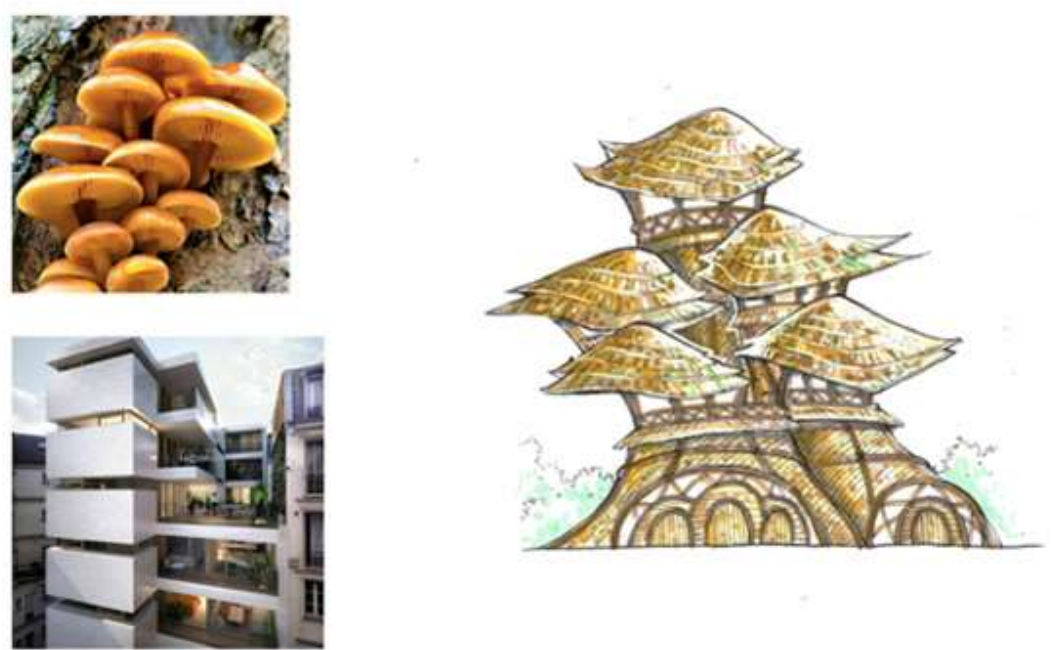

Gambar 16. Hasil rekayasa penerapan biomimicry pada hunian bambu untuk Desa Wisata Kerajinan Bambu Brajan (e).

(Sumber : Analisis peneliti, 2019) 


\section{Kesimpulan}

Penelitian yang berjudul "Bamboo House, Desain Interior Hunian Berkelanjutan Desa Wisata Kerajinan Bambu Brajan" menghasilkan ide desain hunian bermaterial bambu sebagai jawaban terhadap problem vital atas hunian yang terdapat di Desa Wisata Kerajinan Bambu Brajan Yogyakarta.

Hunian yang terdapat di Desa Wisata Kerajinan Bambu Brajan menjadi sasaran utama dari penelitian ini. Masyarakat Brajan yang mayoritas bermata pencaharian sebagai pengrajin bambu tidak mengoptimalkan sumber daya alam yang mengangkat desa ini sebagai desa wisata, sehingga output dari produk berbasis material bambu yang dihasilkan belum maksimal. Terdapat kesenjangan yang tinggi antara kebutuhan dengan pengelolaan material bambu di Desa Brajan. Namun potensi dari pemanfaatan sumber daya alam terhadap hunian yang dapat diciptakan masih dapat dikelola secara maksimal.

Hasil dari penelitian ini berupa output terhadap solusi dari perrmasalahan hunian yang ada di Desa Wisata Kerajinan Bambu Brajan. Beberapa alternative desain tercipta berdasarkan hasil analisa penelitian, bentuk hunian bermaterial bambu telah diciptakan dengan penerapan prinsip desain berkelanjutan biomimicry. Dengan adanya visual dari alternative desain berupa gambar ilustrasi, diharapkan dapat mempermudah menciptakan prototype dari desain tersebut.

\section{Daftar Pustaka}

Akinlabi, E. T., Anane-Fenin, K., \& Akwada, D. R. (2017). Bamboo: The Multipurpose Plant. Johannesburg: Springer International Publishing.

Astanto, Setia Budi. (2012). Desain Interior Berkelanjutan dengan Strategi Adaptif Studi Kasus Green School Bali. Yogyakarta : Pascasarjana Institut Seni Indonesia.

Bambu, S. (2016, April 13). Blog Sahabat Bambu. Retrieved from Situs Sahabat Bambu: http:// sahabatbambu.com

Jones, L. (2008). Environmentally Responsible Design: Green Sustainable Design for Interior Design. New Jersey: John Wiley \& Sons, Inc.

J. Moleong, L. (2017). Metodologi Penelitian Kualitatif (edisi revisi). Bandung: PT REMAJA ROSDAKARYA.

\section{Sumber Internet}

Apriando, Tommy. 2015. Brubuh, Kearifan Masyarakat Jawa Menjaga Hutan, https:// www.mongabay.co.id/2015/02/12/brubuhkearifan-masyarakat-jawa-menjaga-hutan/, diakses pada tanggal 7 Oktober 2019).

Farouqi, Mehmed. 2013. Desa Wisata Brajan, "Sentra Kerajinan Bambu" https://www. kompasiana.com/cyberboypower/552940 9 a6ea834e41f8b45c4/desa-wisata-brajansentra-kerajinan-bambu, diakses tanggal 6 Oktober 2019.

https://www.indotelko.com/liputan-khusus/ rumah-kreatif-bumn/read/1483413008/ desa-wisata-brajan-kerajinan-bambu-yangmendunia, diakses tanggal 6 Oktober 2019.

https://www.archdaily.com/81585/ $\mathrm{t} h \mathrm{e}-\mathrm{g} \mathrm{r}$ e e $\mathrm{n}-\mathrm{s} \mathrm{c} \mathrm{h}$ o o l - p t $\mathrm{bambu} / 5012 \mathrm{~b} 12 \mathrm{f} 28 \mathrm{ba} 0 \mathrm{~d} 147 \mathrm{~d} 00048 \mathrm{a}$-thegreen-school-pt-bambu-photo. Diakses pada tanggal 10/9/2019 pukul 12.09 PM.

https://www. setouchiexplorer.com/lightshodoshima/ diakses pada tanggal 10/9/2019 pukul 13.22 PM. 